\title{
Health Diplomacy in Pandemical Times
}

\author{
Tanisha M. Fazal
}

\begin{abstract}
One likely effect of the COVID-19 pandemic will be an increased focus on health diplomacy, a topic that has rarely been taken up by international relations scholars. After reviewing existing literature on health diplomacy, I argue for the utility of distinguishing states' aims from their practices of health diplomacy in advancing our understanding of when states engage in health diplomacy with a bilateral, regional, or global scope. The recent history of twenty-first century infectious disease outbreaks suggests a possible move away from health diplomacy with global participation. COVID-19 provides numerous examples, from widespread criticism of the World Health Organization to increased bilateral health aid and the creation of a regional vaccine initiative. As pandemics become more frequent, however, more localized health diplomacy is likely to be less effective, given the necessity of global mitigation and containment.
\end{abstract}

Historically, health diplomacy has lingered on the sidelines of international relations. From the European Union's regional vaccine initiative to India's delivery of hydroxychloroquine to the United States in April 2020, however, the COVID-19 pandemic has provided numerous examples of states centering health in foreign policy, a practice likely to continue after the pandemic. As such, it is time to forward health diplomacy in international relations scholarship and practice.

Not all health diplomacy is about health. I define health diplomacy as international aid or cooperation meant to promote health or that uses health programming to promote non-health-related foreign aims. While philanthropic organizations such as the Bill and Melinda Gates Foundation have been increasingly involved in global health, I focus on health diplomacy as practiced by states as a first step in investigating this topic.

States select among a wide array of options in formatting their health diplomacy, from engagement with global intergovernmental organizations such as the World Health Organization (WHO) to bilateral aid calibrated to support existing foreign investments. The increased pace of pandemics in the twenty-first century has placed states' choices in executing health diplomacy into sharp relief. The nature of pandemics requires international cooperation for mitigation and containment. But pandemics also create opportunities for states to pursue foreign policy goals that primarily serve their

Editor's note: This article is part of an online supplemental issue on COVID-19 and international relations. The authors were invited by IO's editorial team and guest editor Michael C. Horowitz. The manuscript was reviewed based on written non-anonymous reviewer comments and during an online workshop. The revised manuscript was evaluated by the IO editorial team. We appreciate the support of Perry World House at the University of Pennsylvania for making this possible. 
national interest rather than serving global health. A key question around health diplomacy is, therefore, under what conditions do states opt for one form or another?

States' primary aim in a pandemic is the protection of the physical and economic health of their own citizens. At times, this aim is best achieved by working with IGOs created as forums for health issues; health diplomacy practiced in this manner can leverage reduced transaction costs and see increased information sharing, ${ }^{1}$ which is both necessary in a pandemic and a key aim of the WHO's current International Health Regulations. ${ }^{2}$ States also may use health diplomacy to build goodwill and soft power, as well as to pursue humanitarian aims. During pandemics, states assess the urgency of their various aims and the best means to achieve them via health diplomacy. A key variable is whether states view existing institutional structures for cooperation as adequate to the task of addressing their own needs during a particular pandemic. When states move away from global health institutions in their responses to pandemics, they risk creating the recursive effect of undermining these institutions' ability to address future pandemics effectively.

I consider how health diplomacy has developed during COVID-19 and past global health crises with three aims. First, I hope to introduce more international relations scholars to the field of health diplomacy. While international relations scholars have been researching global health for some time, ${ }^{3}$ much of this literature has emerged from the discipline of public health. In addition to learning from public health experts on this subject, international relations scholars can contribute by centering the role of politics in this discussion. Second, I offer a framework for health diplomacy, distinguishing between humanitarian, strategic, and other ends and between multilateral, bilateral, and other means. Third, I apply this framework to recent global disease outbreaks to see if any patterns or trends can be discerned. We currently lack understanding of the causes and consequences of using one type of health diplomacy rather than another. I identify a shift away from global, multilateral health diplomacy as a potential emerging trend. I also consider possible reasons for this trend, focusing on variables such as international rivalry and the relative degree of difficulty posed by various outbreaks.

\section{What is Health Diplomacy?}

In part because much of the literature on health diplomacy has emerged from public health and not from political science or international relations, it has often focused on how diplomacy can serve health, rather than on the international politics of health. Both the nascent nature of this literature and this aim are reflected in ongoing debates over definitions of health diplomacy.

1. Keohane 1984.

2. Worsnop 2017.

3. See for example Davies et al. 2014; Enemark 2017; Harmon 2017; Worsnop 2017. 
Existing literature on health diplomacy suggests two distinctions international relations scholars may wish to make. The first refers to the tension between the aims of shoring up global public health on the one hand and serving the national interest, however defined, on the other. The second distinction refers to the means of health diplomacy, particularly whether it is executed multilaterally, with a global scope, on a regional basis, and/or bilaterally.

Much of the existing literature on health diplomacy collapses these two dimensions. In a widely-cited article, Kickbusch, Silberschmidt, and Buss, for example, define the aim of global health diplomacy as capturing "multi-level and multi-actor negotiation processes that shape and manage the global policy environment for health." 4 This definition equates health diplomacy with health governance and agreements to improve global health. I suggest that health diplomacy is distinct from health governance because states' aims in engaging health diplomacy may not be directed toward "[managing] the global policy environment for health."

Defining health diplomacy in terms of its aims is also to some extent reflected in the type of health diplomacy being defined. Kickbusch, Silberschmidt, and Buss set out to define "global health diplomacy," not "health diplomacy." Likewise, Adams, Novotny, and Leslie define the aims of global health diplomacy as improving global health. ${ }^{5}$ Lee and Smith note a shift from "traditional" to "new" diplomacy, and define global health diplomacy as "negotiations on population health issues that require collective action worldwide to address effectively." ${ }^{6}$ From this perspective, global health diplomacy efforts are based on something akin to the ordering principles that Ruggie sees as foundational to multilateralism. ${ }^{7}$ By this logic, these efforts ought to be centered on global institutions such as the WHO, whose stated objective is "the attainment by all peoples of the highest possible level of health."

Authors who focus on "health diplomacy" rather than "global health diplomacy" tend to identify the aims of health diplomacy with the strategic aims of countries engaged in such diplomacy. Drager and Fidler, for example, describe health diplomacy as "mechanisms to manage the health risks that spill into and out of every country." ${ }^{9}$ Katz et al. note that US investments in global health secure favorable perceptions toward the US, ${ }^{10}$ while Vanderwagen sees health diplomacy as a way of "winning hearts and minds." 11 As Feldbaum and Michaud note, such definitions conceive of health interventions as justified by national interest, ${ }^{12}$ such as China's recent

4. Kickbusch, Silberschmidt, and Buss 2007.

5. Adams, Novotny, and Leslie 2008.

6. Lee and Smith 2011.

7. Ruggie 1992.

8. WHO Constitution, Article 1, retrieved from <https://www.who.int/governance/eb/who_constitution_ en.pdf>.

9. Drager and Fidler 2007.

10. Katz et al. 2011.

11. Vanderwagen 2006.

12. Feldbaum and Michaud 2010. 
considerable health investments in sub-Saharan Africa, which are widely understood to be an adjunct to the PRC's Belt and Road Initiative (BRI).

The aims of securing global health and serving the national interest need not be in tension. This is the argument of many global health advocates, who point out that better global health can be viewed as a public good. But as with negotiations over the mitigation of climate change, states often put short-term, individual benefit over longer-term collective goods. Note also that while I would generally group humanitarian aims with the aim of serving global public health, there are countries such as Cuba whose bilateral health diplomacy has been governed by humanitarian principles as well as ideological aims. ${ }^{13}$ Similarly, and as shown in Figure 1, not all participants in global multilateral efforts have the betterment of global public health as their principal aim.

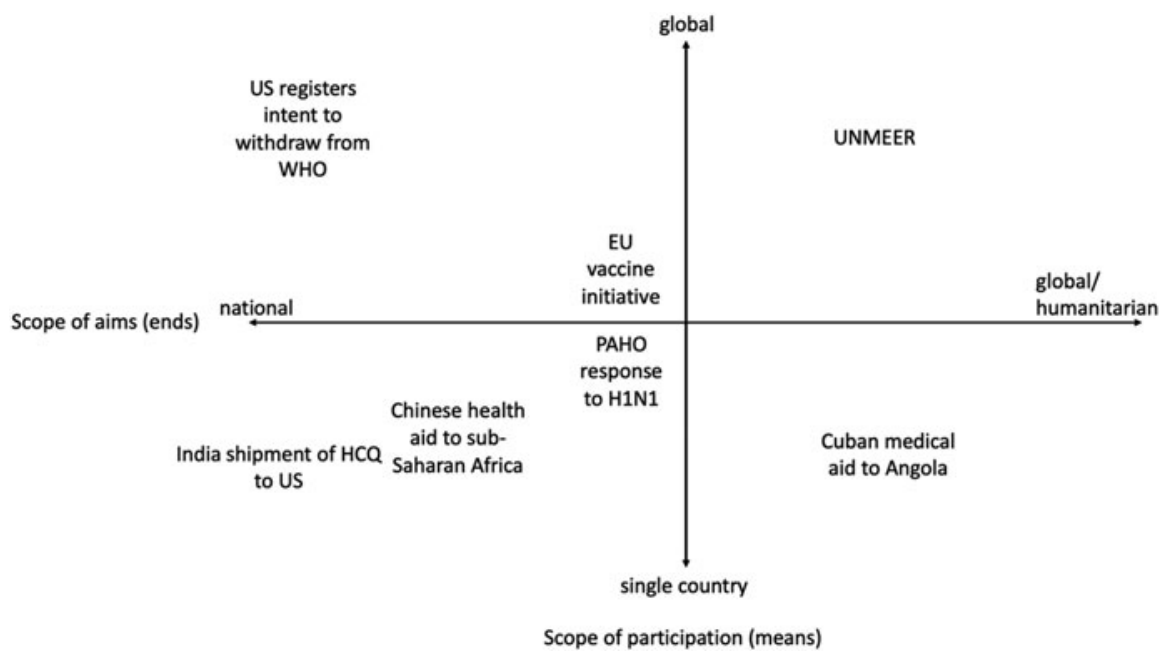

FIGURE 1. Health diplomacy framework

The dimensions of means and ends laid out in Figure 1 suggest avenues of research collaboration for scholars of health diplomacy and international relations. Several experts in health diplomacy have called for integrating theories of international relations into their field. Beyond a common invocation of soft power ${ }^{14}$ and one attempt to apply the levels of analysis framework to health diplomacy, ${ }^{15}$ however, this effort appears to have mostly stalled. Now would be a fruitful time to re-engage. For example, a key question among scholars of foreign aid is whether aid is designated primarily along strategic or humanitarian lines. ${ }^{16}$ Studies of diplomacy illustrate a divide

13. Feinsilver 1993.

14. Lee and Smith 2011.

15. Ruckert et al. 2016.

16. See Lancaster 2006; Lumsdaine 1993; Vreeland and Dreher 2014. 
between those who view it as superfluous and those who are more optimistic about its effects, particularly focusing on psychological theories of diplomacy. ${ }^{17}$ Scholars of health diplomacy might consider the differences between diplomacy on one hand and foreign policy writ large on the other. ${ }^{18}$ With respect to the former, the practice turn in international relations suggests promising avenues of inquiry, particularly with the creation of new training programs for global health diplomats. ${ }^{19}$

\section{Health Diplomacy in Past Pandemics}

Mapping health diplomacy in recent pandemics onto the framework sketched out in Figure 1 suggests a drift away from health diplomacy focused on IGOs with global scope. But mitigation of pandemics requires a global response, especially given today's high level of globalization. There was little global coordination during the 1918 influenza outbreak ${ }^{20}$ - which is frequently invoked as a comparison to COVID-19-but medicine, public health, epidemiology, and global governance have all come a long way since then. Not only have IGOs focused on healthsuch as the WHO - been created, but even bitter rivals have cooperated over health, as when the US and the Soviet Union spearheaded a joint effort through the WHO to eradicate smallpox. ${ }^{21}$ Considerable global health surveillance resources were devised during and revised in the wake of the 2003 SARS epidemic, and in the global response to Ebola in West Africa in 2014.

Bilateral health diplomacy has also continued. While investments are often made bilaterally and multilaterally, states and other organizations must decide how to deploy limited resources. Along these lines, the following review of health diplomacy in recent pandemics is structured around two questions. What was the primary form of health diplomacy? And which type of diplomacy was most effective in containing the disease?

My loose universe of cases is twenty-first century outbreaks of new diseases spread primarily by person-to-person contact. I restrict my analysis to diseases spread by person-toperson contact to ease comparison with COVID-19, which means excluding polio in 2014 and Zika in 2016.22 In reviewing past health diplomacy around five outbreaks-SARS in 2003, H1N1 in 2009, MERS (still ongoing) starting in 2012, Ebola in West Africa in 2014, and Ebola in the Democratic Republic of Congo in 2018-I find substantial, perhaps increasing, levels of bilateral and regional health diplomacy.

17. See Holmes 2013; Lebovic and Saunders 2016, 107; Yarhi-Milo 2014.

18. Constantinou and Sharp 2016, 4.

19. See Adler and Pouliot 2011; Adler-Nissen 2008; Kickbusch et al.; 2007 Mitzen 2006.

20. See Garrett 2005; Koblentz 2009; Redd et al. 2010; Saunders-Hastings and Krewski 2016.

21. Manela 2010.

22. The HIV/AIDS pandemic is excluded because it began much earlier, although it represents a fascinating comparison for future research. 


\section{SARS 2003}

Initially diagnosed as atypical influenza in China's Guangdong province in January 2003, SARS' first known victim fell ill in November 2002. ${ }^{23}$ According to the US CDC, SARS killed 774 people and infected 8,098 from November 2002 to July 2003. ${ }^{24}$ It spread to over twenty-five countries. ${ }^{25}$

The World Health Organization served as a coordinating and surveillance organization in the case of SARS. The WHO stood up the Global Outbreak Alert and Response Network (GOARN) in 2000, leveraging and creating significant new opportunities for surveillance, communication, and scientific cooperation across borders. ${ }^{26}$ Via GOARN, the WHO dispatched experts to areas experiencing outbreaks in ways not done previously. The WHO counts the multilateral response to SARS as a success: "The world rose to the challenge of SARS with unprecedented scientific collaboration and public-health determination ... In coordinating the global response, WHO aimed at the outset to help contain transmission in affected countries, seal off opportunities for further international spread, and prevent SARS from becoming endemic." 27 Likewise, a National Academy of Medicine report notes "the quality, speed, and effectiveness of the public health response to SARS brilliantly outshone past responses to international outbreaks of infectious disease ... The World Health Organization deserves credit for initiating and coordinating much of this response." ${ }^{28}$ Part of the success of the SARS response was the end of community transmission by July 2003, at which point the most affected countries were declared "SARS-free."

Additional significant bilateral efforts occurred during and emerged after the SARS outbreak. The US and China developed a health partnership around SARS when the US Department of Health and Human Services developed a relationship with the Chinese Ministry of Health. The United States' CDC and China's National Influenza Center also engaged in scientific and public health collaborations to improve analysis and surveillance. These and similar collaborations continued throughout the 2010s. ${ }^{29}$ Also following SARS, the US CDC created the International Emerging Infections Program (IEIP), which sends CDC staff to ten regional centers around the globe. ${ }^{30}$

These successes notwithstanding, SARS also exposed major weaknesses in public health. National public health ministries underwent reform in China, Hong Kong,

23. Knobler et al. 2004, 4-5; For a full chronology, see WHO 2006.

24. "Frequently Asked Questions About SARS." Center for Disease Control and Prevention, retrieved from <https://www.cdc.gov/sars/about/faq.html>.

25. "Summary of probable SARS cases with onset of illness from 1 November 2002 to 31 July 2003." World Health Organization, retrieved from <https://www.who.int/csr/sars/country/table2004_04_21/en/>.

26. WHO 2006, 52.

27. Ibid., 49-50.

28. Knobler et al. 2004, 2-3.

29. Bouey 2019, 12-3.

30. Rao et al. 2017. 
Taiwan, and Canada. ${ }^{31}$ There was significant condemnation of China for being slow to share news of the disease. ${ }^{32}$ As a result, China improved its domestic surveillance capabilities, and also devoted considerable resources toward a robust program of bilateral health diplomacy, especially in Asia and sub-Saharan Africa, in part to rehabilitate its image in the domain of global health. SARS was a watershed for Chinese health diplomacy. ${ }^{33}$

The SARS outbreak saw significant multilateral cooperation, driven principally by the desire to stop the spread of the disease. While hailed as a success, this cooperation mostly took the form of information-sharing and technical assistance. Although the response to SARS included bilateral efforts aimed at eliminating the disease, it was more notable in prompting a subsequent increase in Chinese bilateral health diplomacy around the world. ${ }^{34}$ Bilateral health diplomacy as a response to SARS was driven more by strategic than health interests, even as it was in its early stages.

\section{HIN1 (2009)}

Mexico was the epicenter of the 2009 outbreak of H1N1, a strain of influenza. From 2009 to 2018, H1N1 killed 75,000 people and infected 100.5 million. ${ }^{35}$ By mid-2009, it had spread to over 150 countries. ${ }^{36} \mathrm{H} 1 \mathrm{~N} 1$ - known at the time as swine flu-was particularly concerning because of possibly higher morbidity in pregnant women. ${ }^{37}$

The H1N1 outbreak was the first to test the WHO's new International Health Regulations (IHR). The new IHR, which had been revised in 2005 in the wake of the 2003 SARS outbreak, were meant to improve disease reporting and surveillance, ensure that states did not impose unnecessary travel restrictions in response to new outbreaks, and improve respect for human rights during outbreaks. The new IHR could strengthen the WHO's power substantially, and allowed for the declaration of Public Health Emergencies of International Concern (PHEIC).

The verdict on the regulations' success, however, was mixed. ${ }^{38}$ On one hand, the WHO acted relatively quickly to issue a global alert and gather experts to respond to the outbreak. Both Mexico and the US also quickly reported the new influenza to the WHO. On the other hand, a key concern that emerged in the revision of the IHR was

31. See Bouey 2020; Tam 2018; Taylor 2020; Wang, Ng, and Brook 2020, 1341.

32. "Please Lie Less."

33. Chan, Chen, and Jin 2010.

34. See Chan, Chen, and Jin 2010; Youde 2010.

35. "The burden of the influenza A H1N1pdm09 virus since the 2009 pandemic." Center for Disease Control and Prevention, retrieved from <https://www.cdc.gov/flu/pandemic-resources/burden-of-h1n1. html . Note that the WHO declared the H1N1 pandemic over in August 2010.

36. "Pandemic (H1N1) 2009 - update 60." World Health Organization, retrieved from <https://www. who.int/csr/don/2009_08_04/en/>.

37. "Novel Influenza A (H1N1) Virus Infections in Three Pregnant Women --- United States, April-May 2009." Center for Disease Control and Prevention, retrieved from <https://www.cdc.gov/mmwr/ preview/mmwrhtml/mm5818a3.htm>.

38. Kamradt-Scott and Rushton 2012. For a useful summary of the reasons for the revision of the IHR, see Youde 2015. 
over excessive restrictions such as those on travel and agriculture. Several Latin American countries, as well as China and Singapore, instituted travel and/or quarantine restrictions on flights and passengers to and from Mexico and the United States. ${ }^{39}$ Additionally, live pig populations were culled worldwide, and several countries instituted bans on imports of pork products. Thus, while the WHO directed a global effort, its guidance was violated with some frequency. Kamradt-Scott reports that the organization's efforts in this case are widely viewed as a failure. ${ }^{40}$

Regional and bilateral efforts were significant, and more successful. The Pan American Health Organization (PAHO) was first notified of the new influenza by Mexico and then the US. PAHO, which is part of both the Inter-American and WHO systems, served as a North American informational clearinghouse during the outbreak and provided technical capacity to Mexico. ${ }^{41}$ Mexican-US-Canadian cooperation throughout was critical, especially regarding sample sharing and vaccine distribution; Mexico's working relationship with Canada was especially strong. ${ }^{42}$ On the bilateral front, the US CDC sent personnel and testing materials, and USAID sent $\$ 5$ million in aid to Mexico. ${ }^{43}$ China also sent a $\$ 3$ million donation in the form of personal protective equipment (PPE) and infrared scanners. ${ }^{44}$

The brevity of the $\mathrm{H} 1 \mathrm{~N} 1$ outbreak makes it challenging to assess the relative weight of global, regional, and bilateral efforts. While the WHO succeeded in its role as an information clearinghouse, this success may have been due as much to Mexico's domestic surveillance effort as to the WHO's capabilities. ${ }^{45}$ With regard to initial reporting and classification of the disease and disease control, regional and bilateral efforts appear to have been more numerous and effective in responding to H1N1.

\section{MERS (2012)}

The first known cases of Middle East Respiratory Syndrome (MERS) were documented in Saudi Arabia and in the UK in 2012. Since then, 858 people have died from MERS and 2,494 have been infected. ${ }^{46}$ The MERS outbreak continues at this writing, with fifteen cases reported in March 2020 in Saudi Arabia. ${ }^{47}$ While nearly thirty countries have reported cases of MERS, it is largely contained to the Middle East.

Compared to the response to SARS and H1N1, the WHO has been less successful in managing MERS; there also appear to have been fewer regional and bilateral

39. Kamradt-Scott and Rushton 2012, 13-4.

40. Kamradt-Scott 2016.

41. Katz 2009.

42. Ear 2012, 57-8.

43. "USAID Provides \$5M in Emergency Support as Swine Flu Spreads."

44. Lange 2009.

45. Ear 2012.

46. "Middle East respiratory syndrome coronavirus (MERS-CoV)." World Health Organization, retrieved from <https://www.who.int/emergencies/mers-cov/en/>.

47. "Middle East respiratory syndrome coronavirus (MERS-CoV) - Saudi Arabia." World Health Organization, retrieved from <https:/www.who.int/csr/don/05-may-2020-mers-saudi-arabia/en/>. 
efforts to contain the disease. This is both surprising and troubling given that the WHO's response to MERS in 2012 was informed by its response to SARS in 2003 and H1N1 in 2009. The revision of the International Health Regulations in 2005 was meant to improve countries' reporting rates of new diseases to the WHO. Like China in 2003, however, Saudi Arabia was widely chastised for not having reported the outbreak in a timely manner. ${ }^{48}$

The WHO's anemic response to MERS was partially caused by significant budgetary shortfalls in 2012, particularly in the area of managing infectious diseases. ${ }^{49}$ This shortfall was in part driven by the Great Recession of 2008. But there were also concerns about the efficacy of the WHO. While it is criticized for its inability to enforce compliance with, for example, reporting of new diseases, it is also a membership organization that lacks the authority to compel states to abide by its guidelines. ${ }^{50}$ This is the narrow path that many intergovernmental organizations must navigate; the WHO's navigation has been criticized in recent years.

There was significant international research collaboration around MERS that could be classified as bilateral health diplomacy. Universities and ministries of health from Germany, Hong Kong, Jordan, the Netherlands, the US, Tunisia, and Saudi Arabia all devoted resources to analyzing MERS. ${ }^{51}$ China also lent technical assistance. ${ }^{52}$

While both global and bilateral health diplomacy were in evidence during the onset of MERS, neither was lauded as particularly effective. MERS remains contained to the Middle East and has drawn little international attention since 2012. The attention of much of the global public health community was pulled away two years later, with a large Ebola outbreak in West Africa.

\section{Ebola (2014)}

Ebola emerged in Guinea in early 2014, then spread quickly to neighboring countries. By the time the 2014 declaration of a PHEIC was lifted in early 2016, 11,310 people had died and 28,616 had been infected..$^{53}$ The 2014 Ebola outbreak was largely contained to Guinea, Liberia, and Sierra Leone.

The multilateral efforts to address the Ebola outbreak in West Africa in 2014 further reveal the institutional limitations of the WHO and some curious patterns and preferences in global versus bilateral health diplomacy. The United Nations Mission for Ebola Emergency Response (UNMEER), launched as a wide-ranging multilateral effort in September 2014 by UN Secretary-General Ban Ki-Moon (rather than the WHO's Director-General), played a more central role than the

48. Branswell 2013.

49. Youde 2015.

50. Busby 2020.

51. Williams et al. 2015.

52. Yan 2017.

53. "2014-2016 Ebola Outbreak in West Africa." Center for Disease Control and Prevention, retrieved from <https://www.cdc.gov/vhf/ebola/history/2014-2016-outbreak/index.html>. 
WHO. It was UNMEER that coordinated international contributions, which included over $\$ 5$ billion in donations. ${ }^{54}$

That the WHO did not lead the response is a function of at least two factors. First, the WHO had focused its limited resources on MERS, leaving relatively little in personnel and funding to assist in the Ebola response. ${ }^{55}$ Second, the WHO was and is not equipped to set up the Ebola Treatment Units (Ebola field hospitals/ETUs) that were deemed necessary to the response. The ETUs were coordinated by UNMEER and provided by organizations like Médicins sans Frontières (MSF) and the US military.

One of the first steps on the path to UNMEER was bilateral US-China talks. Barack Obama and Xi Jinping issued a joint announcement in November 2014 that they would cooperate in their response to the Ebola outbreak. This communiqué potentially suggested a new kind of bilateral health diplomacy, one characterized by cooperation between two great powers to address a health crisis in a different set of states. According to a Carter Center report, however, China quickly pivoted to a multilateral approach. ${ }^{56}$ This shift is consistent with China's active engagement of international organizations, and also with the general claim that China is managing its rise as a great power via these institutions. ${ }^{57}$

While the PRC may have preferred a multilateral approach in 2014 to avoid further complicating its relationship with the US, it also engaged in significant bilateral health diplomacy. China's commitment to health diplomacy in Africa is decades old $^{58}$ and politically lucrative. As Jennifer Bouey notes: "Many attributed the success of China gaining a seat at the United Nations in 1971 to the support from the delegates of African countries." 59 Sub-Saharan Africa is also critical to China's Belt and Road Initiative. The PRC may have thus opted for the optics of multilateral health diplomacy while simultaneously leveraging its existing bilateral health diplomacy infrastructure in the region.

Recipients, however, judged Chinese health aid to be less effective than the multilateral effort and the US-led effort. The most effective program was run via Liberia's Ministry of Health and Social Welfare (MOHSW), but China rarely participated in those meetings. ${ }^{60}$ By contrast, the British and Canadians in Sierra Leone, and US and German forces in Liberia were perceived to have been effective. ${ }^{61}$

The US and China did work together in other ways to respond to the 2014 Ebola outbreak. The Carter Center reports laboratory, logistics, and research/epidemiological collaboration. ${ }^{62}$ Some of these collaborations, especially on the research

54. Kamradt-Scott, Smith, and Harman 2015, 8.

55. Ibid., 6.

56. Aboaf n.d., 1.

57. Johnston 2007.

58. See Bouey 2019, 2, 4; Youde 2010, 153-5.

59. Bouey 2019, 2.

60. Kamradt-Scott, Smith, and Harman 2015, 11.

61. Ibid., 14.

62. Aboaf n.d. 2. 
front, were limited by concerns over patent infringement. ${ }^{63}$ Despite this collaboration and China's historical commitment to bilateral health diplomacy in the region, the scale of US contributions was at least an order of magnitude larger. ${ }^{64}$

Ultimately, health diplomacy led by the US-which was also the largest donorwas viewed as more effective than efforts led by international governmental organizations in addressing the 2014 Ebola outbreak. Specific countries were given credit for their efforts, suggesting a strong bilateral flavor to this one-off multilateral coalition. As Kamradt-Scott et al. report a UN official saying, "had the Americans simply driven from the airport to their base and not done another thing the mission would have been a success. It was a massive demonstration of goodwill." ${ }^{65}$ British forces in Sierra Leone received a similar reception. ${ }^{66}$ With the exception of NGOs such as MSF, however, individual countries were given credit for the success more so than international governmental organizations.

\section{Ebola (2018)}

The resurgence of Ebola in 2018, this time in the Democratic Republic of Congo, presented both a more and less challenging problem than in 2014. The scale of the outbreak has been much smaller; over 28,000 people were infected and 11,000 died because of the 2014 outbreak, while approximately 3,500 were infected and 2,280 died because of the 2018 outbreak. But ongoing political violence in DRC has hindered provision of aid. ${ }^{67}$ At the same time, the WHO appears to have learned from its failures in 2014, responding more effectively four years later. Bilateral contributions like those made in 2014 seem to have played less of a role in the response to the 2018 outbreak.

Since 2014, the WHO has stood up an emergency fund, reorganized internally, and made important leadership changes. ${ }^{68}$ Funds contributed by member states to respond to the 2014 crisis were held over and used to address the 2018 outbreak. But the WHO's effectiveness ought not be overstated; it took four attempts for this outbreak to be declared a PHEIC. ${ }^{69}$

While the discharge of the (then) last Ebola patient in DRC was celebrated in March $2020^{70}$ (as COVID-19 was spreading globally), new cases re-emerged in early April $2020 .^{71}$ Nonetheless, especially compared to the 2014 outbreak, the

63. Aboaf n.d., 2.

64. Ibid., 3-4.

65. Kamradt-Scott, Smith, and Harman 2015, 14.

66. Even for those contributors, reviews were mixed, with some criticism of Western forces constructing field hospitals too slowly and separating themselves from the local community. Kamradt-Scott, Smith, and Harman 2015, 14-5; Autesserre 2014.

67. Fast 2014.

68. Michaud and Kates 2018, 3-4.

69. Moss, Michaud, and Kates 2019, 2-4.

70. Socé Fall 2020.

71. GWO, "New Ebola case confirmed in the Democratic Republic of Congo," 11 April 2020, Retrieved from <https://ghanawebonline.com/new-ebola-case-confirmed-in-the-democratic-republic-of-congo/>. 
Ebola outbreak that began in DRC in 2018 has been relatively contained. While the WHO can take some of the credit, other factors, such as DRC's past experience with Ebola and the availability of a vaccine and an experimental therapeutic, have likely also played a significant role. ${ }^{72}$

Bilateral health diplomacy appears to be more limited. China has offered technical assistance and supplies but does not appear to work at the heart of the outbreak. ${ }^{73}$ While the United States initially made important financial contributions, the Trump administration has been reluctant to offer additional funding. And US personnel have been called back due to security concerns, as have personnel from NGOs such as MSF. ${ }^{74}$

\section{Health Diplomacy around COVID-19}

COVID-19 emerged in Wuhan, China in late 2019, and spread quickly to nearly every country in the world. At this writing, there have been over eighteen million cases of COVID-19 globally and 700,000 deaths. ${ }^{75}$ COVID-19 is often compared to the 1918 influenza pandemic because of the breadth and speed of its spread, although at least to date, its scale is considerably smaller than that of the 1918 pandemic and longer-lasting pandemics such as HIV/AIDS.

The World Health Organization has received a great deal of criticism for its handling of COVID-19. The WHO has been accused of fecklessness vis-à-vis China, using talking points from the Chinese government that understated the seriousness and transmission rates of COVID-19 at its start, and praising China for its initial response to the outbreak. ${ }^{76}$ This kind of informational challenge is typical. China was also slow to report SARS, Saudi Arabia was slow to report MERS, and Sierra Leone, Liberia, and Guinea were slow to report Ebola in 2014. As Catherine Worsnop shows, lack of surveillance capacity and/or fear of economic consequences help explain the slow reporting of outbreaks. ${ }^{77}$ Additionally, the WHO does not have the power to sanction states for reporting failures.

Health diplomacy funneled through the WHO has been fraught during the COVID-19 pandemic. With the possible exception of the World Bank and IMF, which have assisted developing countries, other global and multilateral efforts have stalled. The G20 have put out statements suggesting international commitment, but measures taken have been largely limited to domestic fiscal policy. ${ }^{78}$ The Trump

72. Moss, Michaud, and Kates 2019, 4-6.

73. "China ready to offer expertise for DRC Ebola outbreak: health official." Xinhuanet, 21 May 2018, retrieved from <http://www.xinhuanet.com/english/2018-05/21/c_137193514.htm>.

74. Moss, Michaud, and Kates 2019.

75. WHO Coronavirus Dashboard.

76. Gilsinan 2020.

77. Worsnop 2019.

78. Jain 2020. 
administration has announced that the United States will withdraw from the WHO. From guidance on masking to communication regarding the aerosol transmission of COVID-19, the WHO has been roundly criticized.

The current pandemic has also been characterized by a great deal of bilateral health diplomacy, sometimes in surprising ways. Chinese donations of PPE and testing kits to countries around the world, including the US and Europe, were perhaps to be expected; some follow aid given via the BRI, and others-including to Europe and even past rivals such as Japan-were meant to improve China's image given international criticism of China's initial handling of the outbreak. ${ }^{79}$ The reaction to these donations has been characterized by gratitude as well as disappointment in faulty equipment. ${ }^{80}$ But it is not just China that is sending bilateral aid. One unusual feature of bilateral health diplomacy in COVID-19 has been poorer countries sending aid to richer countries, including to the US. India honored a request by Donald Trump and sent a shipment of hydroxychloroquine to the US after Trump touted the drug's effectiveness. ${ }^{81}$ A Turkish airplane landed at Andrews Air Force base in late April 2020 with a shipment of PPE including masks, face shields, and goggles, all to be donated to the US. ${ }^{82}$ Taiwan also sent masks to the US, and was criticized by China for engaging in "mask diplomacy." 83 While the US currently has the highest case count in the world, it would be difficult to argue that these deliveries were driven by humanitarian motivations; even if drugs like hydroxychloroquine were proven to be effective, ${ }^{84}$ there are many other countries in much greater need of assistance than (and from) the US. This kind of bilateral health diplomacy is driven by a desire to shore up relations with the US and curry the favor of the Trump administration. As of this writing, bilateral health diplomacy initiated by the Trump administration itself appears to be minimal, especially when compared to past pandemics. ${ }^{85}$

COVID-19 provides many different examples of health diplomacy, but is mostly characterized by fragmentation. A series of regional responses, such as an EU vaccine initiative independent of the $\mathrm{WHO}$, has emerged amid this fragmentation. Like the effort to respond to Ebola in 2014, the center of gravity of health diplomacy during COVID-19 may be shifting away from global institutions like the WHO.

79. See Burton 2020; Myers and Rubin 2020.

80. Bradsher 2020.

81. Arora and Khanna 2020. In response, Trump announced that the US would donate ventilators to India. Gupta 2020.

82. Hansler, Alvarez, and Tuysuz 2020.

83. "US secretary of state expresses gratitude for Taiwan's face mask donations." Taiwan News, 9 April 2020, retrieved from <https://www.taiwannews.com.tw/en/news/3912956>; Pomfret 2020.

84. Hydroxychloroquine has not been shown to be effective prophylactic. Boulware et al. 2020 .

85. Jakes 2020. 


\section{Why the Difference?}

The recent past of health diplomacy raises the following question: under what conditions do states pursue health diplomacy on a bilateral, regional, or global scale in pandemics? Bearing in mind that it may be too soon to tell, the twenty-first century outbreaks to date suggest a possible drift away from health diplomacy based on global participation. But why would states make this move?

\section{Fewer Participants for Harder Problems}

Precisely because they are intergovernmental state-based organizations, global health organizations such as the WHO will always be limited by claims of state sovereignty and attendant issues of organizational design. ${ }^{86}$ The world has turned to the WHO to manage COVID-19, but perhaps with an unclear understanding of the organization's role and capacity. As Jeremy Youde writes: "The organization [WHO] focuses most of its energies and resources on program development and information sharing. It acts as a central repository of health data and information, working with countries as requested to help translate those data into effective policies." 87 As an information clearinghouse, a source of scientific expertise, and a facilitator of deploying that expertise, WHO is limited in what it can do. In the most pressing cases, the structure of global health organizations may be too limiting, leading states to turn to alternative means to achieve their desired ends.

Bilateral and regional health diplomacy are two such means. States may invest in bilateral or regional health diplomacy in the most pressing cases for at least two strategic reasons. First, they may view bilateral/regional health diplomacy as more effective in containing disease than broader, globally inclusive health diplomacy. Second, states may see longer-term strategic gain in using bilateral/regional health diplomacy that helps them develop or shore up relationships that may serve future foreign policy interests. In this respect, a shift away from health diplomacy with a global scale may mirror a broader documented trend in foreign aid focused on serving the interests of the giver more than of the receiver. ${ }^{88}$ From a global health perspective, however, such strategies in the face of a global pandemic are profoundly un-strategic, as the course and consequences of the pandemic cannot be resolved or addressed absent global cooperation.

\section{US-China Competition}

Bilateral health diplomacy in particular may also reflect a growing rivalry between the US and China. ${ }^{89}$ Health aid is a relatively new domain of competition between 
these two great powers. It is easier to get credit for bilateral than for multilateral aid. ${ }^{90}$ Insofar as there are existing aid paths that can be leveraged in the current context, they may enhance both national security and health outcomes.

In the case of COVID-19, rivalry may increase bilateral health diplomacy for an additional reason: conspiracies emanating from the US and China about the source of the virus present a substantial challenge to global health diplomacy. Even more challenging is a lack of global leadership. The US has clearly retreated from its leadership position. And even if China were willing to step up, its credibility would be severely undermined by its effective violation of the IHR at the beginning of the pandemic. With neither state taking the lead globally, and both looking askance at each other, it is easy to see why there might be a current increase in bilateral health aid. Note, however, that Chinese bilateral health aid has been marked in its presence, while US bilateral health aid has been marked in its absence.

\section{Conclusion}

The relative lack of global health cooperation during the COVID-19 pandemic is both puzzling and troubling for several reasons. First, logic suggests that states are more likely to cooperate in the face of immediate versus distant threats. Leaders ought to view immediate dangers as threats to their tenure, and respond accordingly. ${ }^{91}$ This logic is sometimes used to explain lack of commitment toward measures to address climate change; because the threat is far-off, there is no pressing political need for leaders to respond. ${ }^{92}$ But the danger of COVID-19 is both clear and present. Second, global cooperation and coordination are necessary to address the problem. While island states like New Zealand and Cuba can regulate their borders relatively effectively and thus increase the odds of securing their COVID-19 mitigation successes, most countries are not islands. Given how much international trade contributes to the global economy - and the extent to which that trade relies on travel of goods and people ${ }^{93}$ - the world will either have to accept severe global economic consequences or figure out ways to make travel both safe and possible in the near term. While suggestions such as the creation of "immunity passports" have been floated, their utility is up for debate. ${ }^{94}$ The institution of travel bans has been a much more common response, as have different versions of the centuries-old practice of quarantine. Third, augurs of public health suggest pandemics will become more, not less, frequent. ${ }^{95}$ If states cannot or do not learn how to cooperate more broadly

90. Note, though, that states may be able to "hide" and avoid blame by participating in multilateral efforts. I thank Jeremy Youde for this point.

91. See DiYionne 2011; Edelstein 2017.

92. See Flusberg, Matlock, and Thibodeau 2017; Fredriksson and Gaston 2000, 356.

93. Peters 2015.

94. See Phelan 2020; WHO 2020.

95. Osterholm and Olshaker 2020. 
in the face of a pandemic today, they will have missed the opportunity to create tools to cooperate in similar circumstances in the future.

While the choice among forms of health diplomacy is not either/or, doing more of one might undercut the other. This is not only because resources are limited, but also because investments in health diplomacy may generate path-dependence that can also spill over into other areas. In this respect, COVID-19 may change patterns, rather than levels, of international cooperation. If health diplomacy is following the general trend of development aid toward bilateralism, ${ }^{96}$ international relations scholars have a comparative advantage in considering the consequences of this shift.

A shift to regionalism might be a more-or at least equally-likely outcome. Decades from now, the spread of COVID-19 may appear to have been lightning fast. For many people living in the midst of its spread, however, time may seem to stand still. The immediacy of the need for containment may be more visible and manageable on a regional rather than global level, as disease crosses nearby borders. Similarly, countries such as Australia and New Zealand can create travel bubbles to protect them from contagion as their case counts decline. A shift away from health diplomacy with global participation, however, is likely to be characterized by competition and a lack of coordination. Outside options may be increasing for health diplomacy, but they are not necessarily suited to the challenges of pandemics. ${ }^{97}$ If states continue to exercise these options at the expense of investing in global health institutions, the duration of the current pandemic and of future pandemics will be longer than it would be in a counterfactual world with more robust global pandemical diplomacy.

\section{References}

Aboaf, Callie. n.d. US-China Collaboration in Combating the 2014 Ebola Outbreak in West Africa. In Africa-US-China Trilateral Cooperation Research Series. The Carter Center.

Adams, Vincanne, Thomas E. Novotny, and Hannah Leslie. 2008. Global Health Diplomacy. Medical Anthropology 27 (4):315-23.

Adler, Emanuel, and Vincent Pouliot. 2011. International Practices. International Theory 31 (1):1-36.

Adler-Nissen, Rebecca. 2008. The Diplomacy of Opting Out: A Bourdieudian Approach to National Integration Strategies. Journal of Common Market Studies 46 (3):663-84.

Alesina, Alberto, and David Dollar. 2000. Who Gives Foreign Aid to Whom and Why? Journal of Economic Growth 5 (1):33-63.

Arora, Neha, and Sumit Khanna. 2020. India Exports 50 Million Hydroxychloroquine Tablets to U.S. for COVID-19 Fight. Reuters, April 30.

Autesserre, Séverine. 2014. Peaceland: Conflict Resolution and the Everyday Politics of International Intervention. Cambridge University Press.

Bermeo, Sarah Blodgett. 2017. Aid Allocation and Targeted Development in an Increasingly Connected World. International Organization 71 (4):735-66. 
Bouey, Jennifer. 2019. Implications of US-China Collaborations on Global Health Issues. RAND Corporation.

Bouey, Jennifer. 2020. Strengthening China's Public Health Response System: From SARS to COVID-19. American Journal of Public Health, July.

Boulware, David R., Matthew F. Pullen, Ananta S. Bangdiwala, Katelyn A. Pastick, Sarah M. Lofgren, Elizabeth C. Okafor, Caleb P. Skipper, Alanna A. Nascene, Melanie R. Nicol, Mahsa Abassi, Nicole W. Engen, and Matthew P. Cheng. 2020. A Randomized Trial of Hydroxychloroquine as Postexposure Prophylaxis for Covid-19. New England Journal of Medicine 383 (6):517-25.

Bradsher, Keith. 2020. China Delays Mask and Ventilator Exports after Quality Complaints. The New York Times, April 11.

Branswell, Helen. 2013. Saudi Silence on Deadly MERS Virus Outbreak Frustrates World Health Experts. Scientific American, June 7.

Burton, Guy. 2020. China and COVID-19 in MENA. POMEPS. Accessed 11 August 2020. <https:// pomeps.org/china-and-covid-19-in-mena>.

Busby, Joshua W. Forthcoming. Understanding the Anemic Global Response to COVID-19. Journal of Health Politics, Policy and Law.

Chan, Lai Hah, Lucy Chen, and Xu Jin. 2010. China's Engagement with Global Health Diplomacy: Was SARS a Watershed? PLOS Medicine 7 (4):203-19.

Constantinou, Costas M., and Paul Sharp. 2016. Theoretical Perspectives in Diplomacy. In The SAGE Handbook of Diplomacy, edited by Costas M. Constantinou, Pauline Kerr and Paul Sharp. SAGE.

Davies, Sara E., Stefan Elbe, Alison Howell, and Colin McInnes. 2014. Global Health in International Relations. Review of International Studies 40:825-34.

DiYionne, Kim. 2011. The Role of Executive Time Horizons in State Response to AIDS in Africa. Comparative Political Studies 44 (1):55-77.

Drager, Nick, and David P. Fidler. 2007. Foreign Policy, Trade, and Health: At the Cutting Edge of Global Health Diplomacy. Bulletin of the World Health Organization 85 (3):162.

Ear, Sophal. 2012. Swine Flu: Mexico's Handling of A/H1N1 in Comparative Perspective. Politics and the Life Sciences 31 (1/2):52-66.

Edelstein, David M. 2017. Over the Horizon: Time, Uncertainty, and the Rise of Great Powers. Cornell University Press.

Enemark, Christian. 2017. Influenza Virus Research and EU Export Regulations: Publication, Proliferation and Pandemic Risks. Medical Law Review 25 (2):293-313.

Fast, Larissa. 2014. Aid in Danger: The Perils and Promise of Humanitarianism, Pennsylvania Studies in Human Rights. University of Pennsylvania Press.

Feinsilver, Julie. 1993. Healing the Masses: Cuban Health Politics at Home and Abroad. University of California Press.

Feldbaum, Harley, and Joshua Michaud. 2010. Health Diplomacy and the Enduring Relevance of Foreign Policy Interests. PLOS Medicine 7 (4):1-6.

Flusberg, Stephen J., Teenie Matlock, and Paul H. Thibodeau. 2017. Metaphors for the War (or Race) against Climate Change. Environmental Communication 11 (6): 769-83.

Fredriksson, Per G., and Noel Gaston. 2000. Ratification of the 1992 Climate Change Convention: What Determines Legislative Delay? Public Choice 104:345-68.

Garrett, Laurie. 2005. The Next Pandemic? Foreign Affairs 84 (4):3-23.

Gilsinan, Kathy. 2020. How China Deceived the WHO. The Atlantic, April 12.

Gupta, Shishir. 2020. Trump's 200 Ventilators for India Cost $\$ 2.6$ million, Reaching in 3 Weeks. Hindustan Times.

Hansler, Jennifer, Priscilla Alvarez, and Gul Tuysuz. 2020. Personal Protective Equipment Donated from Turkey Arrives in the US. CNN, April 28.

Harmon, Sophie. 2017. Norms Won't Save You: Ebola and the Norm of Global Health Security. Global Health Governance 11 (2):11-6.

Holmes, Marcus. 2013. The Force of Face-to-Face Diplomacy: Mirror Neurons and the Problem of Intentions. International Organization 67 (4):829-61. 
Jain, Ash. 2020. Trump Just Missed a Perfect Opportunity to Reassert American Leadership. Foreign Policy, April 2.

Jakes, Lara. 2020. Despite Big Promises, U.S. Has Delivered Limited Aid in Global Virus Response. The New York Times, June 7.

Johnson, Tana. 2020. Ordinary Patterns in an Extraordinary Crisis: How International Relations Makes Sense of the COVID-19 Pandemic. International Organization 74 (S1). <https://doi.org/10.1017/ S0020818320000430>

Johnston, Alastair Iain. 2007. Social States: China in International Institutions, 1980-2000. Princeton University Press.

Kamradt-Scott, Adam. 2016. WHO's to Blame? The World Health Organization and the 2014 Ebola Outbreak in West Africa. Third World Quarterly 37 (3):401-18.

Kamradt-Scott, Adam, and Simon Rushton. 2012. The Revised International Health Regulations: Socialization, Compliance, and Changing Norms of Global Health Security. Global Change, Peace \& Security 24 (1):57-70.

Kamradt-Scott, Adam, Frank L. Smith II, and Sophie Harman. 2015. Saving Lives: The Civil-Military Response to the 2014 Ebola Outbreak in West Africa (Final Report). Marie Bashir Institute \& Centre for International Security Studies University of Sydney.

Katz, Rebecca. 2009. Use of Revised International Health Regulations during Influenza A (H1N1) Epidemic, 2009. Emerging Infectious Diseases 15 (8):1165-70.

Katz, Rebecca, Sarah Kornblet, Grace Arnold, Eric Lief, and Julie E. Fischer. 2011. Defining Health Diplomacy: Changing Demands in the Era of Globalization. The Milbank Quarterly 89 (3):503-23.

Keohane, Robert O. 1984. After Hegemony: Cooperation and Discord in the World Political Economy. Princeton University Press.

Kickbusch, Ilona, Thomas E. Novotny, Nico Drager, Gaudenz Silberschmidt, and Santiago Alcazar. 2007. Global Health Diplomacy: Training Across Disciplines. Bulletin of the World Health Organization 85 (12):971-73.

Kickbusch, Ilona, Gaudenz Silberschmidt, and Paulo Buss. 2007. Global Health Diplomacy: The Need for New Perspectives, Strategic Approaches and Skills in Global Health. Bulletin of the World Health Organization 85 (3):230-32.

Knobler, Stacey, Adel Mahmoud, Stanley Lemon, Alison Mack, Laura Sivitz, and Katherine Oberholtzer, eds. 2004. Learning from SARS: Preparing for the Next Disease Outbreak - Workshop Summary. National Academies Press.

Koblentz, Gregory D. 2009. The Threat of Pandemic Influenza: Why Today Is Not 1918. World Medical \& Health Policy 1 (1):71-84.

Lagon, Mark P., and Rachel Sadoff. 2020. America Must Not Allow China to Go Viral in Africa. The National Interest, May 1.

Lancaster, Carol. 2006. Foreign Aid: Diplomacy, Development, Domestic Politics. University of Chicago Press.

Lange, Jason. 2009. China Sends Mexico Medical Aid to Fight Flu Epidemic. Reuters, May 1.

Lebovic, James H., and Elizabeth N. Saunders. 2016. The Diplomatic Core: The Determinants of HighLevel US Diplomatic Visits, 1946-2010. International Studies Quarterly 60 (1):107-23.

Lee, Kelley, and Richard Smith. 2011. What is Global Health Diplomacy? A Conceptual Review. Global Health Governance.

Lipscy, Phillip Y. 2015. Explaining Institutional Change: Policy Areas, Outside Options, and the Bretton Woods Institutions. American Journal of Political Science 59 (2):341-356.

Lumsdaine, David Halloran. 1993. Moral Vision in International Politics: The Foreign Aid Regime, 1949_ 1989. Princeton University Press.

Manela, Erez. 2010. A Pox on Your Narrative: Writing Disease Control into Cold War History. Diplomatic History 34 (2):299-323.

Michaud, Joshua, and Jennifer Kates. 2018. The Latest Ebola Outbreaks: What Has Changed in the International and US Response Since 2014? In Global Health: Kaiser Family Foundation. 
Mitzen, Jennifer. 2006. Anchoring Europe's Civilizing Identity: Habits, Capabilities, and Ontological Security. Journal of European Public Policy 13 (2):270-85.

Moss, Kellie, Joshua Michaud, and Jennifer Kates. 2019. The Current Ebola Outbreak and the U.S. Role:

An Explainer. In Global Health Policy: Kaiser Family Foundation.

Multilateral Aid 2015: Better Partnerships for a Post-2015 World. 2015. OECD.

Myers, Steven Lee, and Alissa J. Rubin. 2020. Its Coronavirus Cases Dwindling, China Turns Focus Outward. The New York Times, March 18.

New Ebola Case Confirmed in the Democratic Republic of Congo. 2020. Geneva/Goma.

Osterholm, Michael T., and Mark Olshaker. 2020. Chronicle of a Pandemic Foretold. Foreign Affairs.

Peters, Margaret. 2015. Open Trade, Closed Borders: Immigration Policy in the Era of Globalization. World Politics 67 (1):114-54.

Phelan, Alexandra. 2020. COVID-19 Immunity Passports and Vaccination Certificates: Scientific, Equitable, and Legal Challenges. The Lancet 395 (10237):1595-8.

Please Lie Less. 2003. The Economist, April 10.

Pomfret, John. 2020. Taiwan Must Participate in the WHO. Global Health is too Important to Play Politics. The Washington Post, April 14.

Rao, Carol Y., Grace W. Goryoka, Olga L. Henao, Kevin R. Clarke, Stephanie J. Salyer, and Joel M. Montgomery. 2017. Global Disease Detection - Achievements in Applied Public Health Research, Capacity Building, and Public Health Diplomacy, 2001-2016. Emerging Infectious Diseases 23: S138-S146.

Redd, Stephen, Thomas R. Frieden, Anne Schuchat, and Peter A. Briss. 2010. 1918 and 2009: A Tale of Two Pandemics. Public Health Reports 125:3-5.

Ruckert, Arne, Ronald Labonté, Raphael Lencucha, Vivien Runnels, and Michelle Gagnon. 2016. Global Health Diplomacy: A Critical Review of the Literature. Social Science and Medicine 155:61-72.

Ruggie, John Gerard. 1992. Multilateralism: The Anatomy of an Institution. International Organization 46 (3):561-98.

Saunders-Hastings, Patrick R., and Daniel Krewski. 2016. Reviewing the History of Pandemic Influenza: Understanding Patterns of Emergence and Transmission. Pathogens 5 (4):66.

Socé Fall, Ibrahima. 2020. Remarks by Dr. Ibrahima Socé Fall, World Health Organization Assistant Director-General, Emergency Response.

Tam, T. 2018. Fifteen Years Post-SARS: Key Milestones in Canada's Public Health Emergency Response. Canada Communicable Disease Report 44 (5):98-101.

Taylor, Adam. 2020. Hong Kong Learned from SARS. Can the United States Learn from Hong Kong? The Washington Post, March 11.

US Secretary of State Expresses Gratitude for Taiwan's Face Mask Donations. 2020. Taiwan News, April 9.

USAID Provides \$5M in Emergency Support as Swine Flu Spreads. 2009. USAID.

Vanderwagen, William. 2006. Health Diplomacy: Winning Hearts and Minds through the Use of Health Interventions. Military Medicine 171 (10):3-4.

Vreeland, James A., and Axel Dreher. 2014. The Political Economy of the United Nations Security Council: Money and Influence. Cambridge University Press.

Wang, C. Jason, Chun Y. Ng, and Robert H. Brook. 2020. Response to COVID-19 in Taiwan: Big Data Analytics, New Technology, and Proactive Testing. JAMA 323 (14):1341-2.

Williams, Holly Ann, Richard L. Dunville, Susan I. Gerber, Dean D. Erdman, Nicki Pesik, David Kuhar, Karen A. Mason, Lia Haynes, Lisa Rotz, Jeanette St. Pierre, Sarah Poser, Sudhir Bunga, Mark A. Pallansch, and David L. Swerdlow. 2015. CDC's Early Response to a Novel Viral Disease, Middle East Respiratory Syndrome Coronavirus (MERS-CoV), September 2012-May 2014. Public Health Reports 130:307-17.

World Health Organization. 2006. SARS: How a Global Epidemic Was Stopped. World Health Organization.

World Health Organization. 2020. "Immunity passports" in the context of COVID-19. 
World Health Organization. "WHO Coronavirus Disease (COVID-19) Dashboard. Accessed 11 August 2020. <https://covid19.who.int>.

Worsnop, Catherine Z. 2017. Domestic Politics and the WHO's International Health Regulations: Explaining the Use of Trade and Travel Barriers During Disease Outbreaks. Review of International Organizations 12 (3):365-95.

Worsnop, Catherine Z. 2019. Concealing Disease: Trade and Travel Barriers and the Timeliness of Outbreak Reporting. International Studies Perspectives 20:344-72.

Yan, Guo. 2017. Development of Global Health Research in China. Journal of Global Health 7 (2).

Yarhi-Milo, Keren. 2014. Knowing the Adversary: Leaders, Intelligence, and Assessment of Intentions in International Relations. Princeton University Press.

Youde, Jeremy. 2010. China's Health Diplomacy in Africa. China: An International Journal 8 (1):151-63. Youde, Jeremy. 2015. MERS and Global Health Governance. International Journal 70 (1):119-36.

\section{Authors}

Tanisha M. Fazal is Professor of Political Science at the University of Minnesota. She can be reached at faza1007@umn.edu.

\section{Acknowledgments}

I thank Pedro Accorsi for valuable and speedy research assistance. I also thank the participants of the $I O$ workshop for this special issue for their comments, along with Joshua Busby, Jeremy Youde, Catherine Worsnop, and the members of the University of Minnesota's Medical Humanitarianism Reading Group.

\section{Key Words}

global health; diplomacy; foreign aid 